\title{
CONDITIONS OF CLINICAL SYMPTOMS AND LIFE OF VANAME SHRIMP IN PREVENTION OF Vibrio alginolyticus INFECTION USING MIANA LEAF EXTRACT
}

\author{
Frida Alifia ${ }^{1 *}$, Dewi Farah Diba ${ }^{1}$, Rusnita ${ }^{1}$, Buana Basir ${ }^{1}$ \\ ${ }^{1}$ Aquaculture Study Program, Balik Diwa Institute of Technology and Maritime Business \\ JI Perintis Kemerdekaan VIII No 8, Makassar City, South Sulawesi Province.
}

*Correspondence: pembaharuan@gmail.com

Received : 2021-06-28

Accepted : 2021-12-22

Keywords :

Vannamei Shrimp, Miana Leaf, Vibrio alginolyticus, Clinical Symptoms, Survival

\begin{abstract}
This study aims to determine the clinical symptoms and survival of white vaname shrimp in the prevention of Vibrio alginolyticus infection using miana leaf extract. The study consisted of 4 treatments and 3 replications. The treatments in this study were 1 treatment and 3 treatments using different concentrations of bacteria, namely $103 \mathrm{CFU} / \mathrm{ml}$, $105 \mathrm{CFU} / \mathrm{ml}$, and $107 \mathrm{CFU} / \mathrm{ml}$. The research was carried out in June-July 2020 at the Hatchery Laboratory of the Faculty of Marine and Fisheries Sciences, Hasanuddin University. Data analysis used descriptive analysis and analysis of variance (ANOVA). The results showed that $A$ (control) shrimp was under normal conditions, treatment B (103 $\mathrm{CFU} / \mathrm{ml})$ was red, treated $\mathrm{C}(105 \mathrm{CFU} / \mathrm{ml})$ was red and had necrosis of the body, and treatment $\mathrm{D}(107 \mathrm{CFU} / \mathrm{ml})$ was shrimp. reddening, necrosis of tail and body segments. The results of data analysis showed that the use of miana leaf extract had a significant effect $(p<0.05)$ on the use of live vaname shrimp. The highest vaname shrimp survival was treatment $A$ (control) at $100 \%$, treatment B (103 CFU $/ \mathrm{ml})$ at $90 \%$, treatment $\mathrm{C}(105 \mathrm{CFU} / \mathrm{ml})$ at $63.33 \%$ and treatment $\mathrm{D}$ (107 CFU/ml) by $40 \%$.
\end{abstract}

\section{INTRODUCTION}

Vannamei shrimp (Litopenaeus vannamei) is a marine fishery commodity that has high economic value both in the domestic and global markets, of which $77 \%$ are produced by Asian countries including Indonesia (Bringgs et al., 2004). Vannamei shrimp disease (Litopenaeus vannamei), can be caused by viruses, bacteria, protozoa, and fungi. According to Paillard et al (2004), and Gonzales (2005) in Nasi et al (2001) said that diseases caused by Vibriosis bacteria have long existed in shrimp ponds, as a result many cultivators have suffered considerable losses. The attack of the disease causes clinical symptoms when exposed to vibrio disease in shrimp including flaky tail (necrosis), shell disease (carapace), red disease, Loose Shell Syndrome (LSS), and white intestine disease (WGD). One of the efforts made to suppress Vibriosis is to utilize miana leaf extract.

One group of bacteria that can cause disease in shrimp is Vibrio alginolyticus. This disease often causes a problem in vaname shrimp which is called flaming bacterial disease. Infected larvae glow in the dark. This bacterial flaming disease is commonly found in 
Journal of Fish Health Vol. 1 (2) - Dec 2021

Alifia et al. (2021)

https://doi.org/10.29303/jfh.v1i2.230

the rainy season, when salinity decreases and there is a large temperature difference between day and night (Amri, 2003).

Indonesia has many types of plants that can be cultivated because they are useful and have great uses for humans in terms of prevention and treatment of disease because they contain chemical components that can be used to prevent or treat disease. One of the plants that contain natural compounds is miana. It has been known for some studies on the active compound in the antimicrobial leaf miana (Coleus scutellarioides (L) B enth) in the form of flavonoids, saponins, steroids, tannins, essential oil, eugenol, polyphenol compounds, alkaloids, ethyl salicylate, calcium oxalate, a compound Rosmarinic Acid RA) (Ridwan, 2010).

Based on previous research on the content of the miana plant, the researcher will examine the clinical symptoms and viability of vaname shrimp in preventing $V$. alginolyticus infection using miana leaf extract (Coleus scutellarioides (L) Benth). The purpose of this study was to determine the clinical symptoms of white vaname shrimp with the use of miana leaf extract in the prevention of Vibrio alginolyticus infection and to determine the survival of vannamei shrimp with the use of miana leaf extract in the prevention of Vibrio alginolyticus infection.

\section{METHODOLOGY}

Time and Place of Research

This research was conducted in June-July 2020 at the Hatchery Laboratory, Faculty of Marine and Fisheries Sciences, Hasanuddin University Makassar.

Research Tools and Materials

The tools used are aquarium, aeration, test tube, micropipette, erlenmeyer, measuring cup, digital scale, material spoon, aluminum foil, plastic wrap, basin, bunsen, ose needle, electric stove, magic stirrer, autoclave, freezer, incubator, and oven. The materials used are white shrimp, miana leaves, Vibrio alginolyticus bacteria, sea water and feed.

\section{Research design}

This study used a completely randomized design (CRD) with 3 treatments with bacterial densities of $10^{3}, 10^{5}, 10^{7} \mathrm{CFU} / \mathrm{mL}$ (Basir, 2013) and 1 control treatment. The treatment is as follows:

A treatment : Administration of miana leaf extract without Vibrio alginolyticus bacteria.

B treatment : administration of miana leaf extract and administration of Vibrio alginolyticus bacteria with a density of $10{ }^{3} \mathrm{CFU} / \mathrm{mL}$.

C treatment : administration of miana leaf extract and administration of Vibrio alginolyticus bacteria with a density of $10{ }^{5} \mathrm{CFU} / \mathrm{mL}$.

D treatment : administration of miana leaf extract and administration of Vibrio alginolyticus bacteria with a density of $10>\mathrm{CFU} / \mathrm{mL}$.

\section{Observed Parameters}

Clinical Symptoms

Clinical symptoms are observed by looking at the abnormal changes that occur. The clinical symptoms of shrimp were observed every 3 hours after administration of miana leaf extract and after the challenge test, then a scoring was carried out on shrimp that showed clinical symptoms of Vibriosis. Scoring of clinical symptoms refers to Lightner and Bell (1998) which has been modified, namely: 
Journal of Fish Health Vol. 1 (2) - Dec 2021

Alifia et al. (2021)

https://doi.org/10.29303/jfh.v1i2.230

a Code : Loss of appetite

b Code : Lost balance

c code : Red walking legs

d code: Swim feet red

e code : Tail blushing

F code : Necrosis of the tail

g code : Shrimp body segment necrosis

Mortality

Mortality data calculates the number of dead and alive shrimp from the beginning of rearing to shrimp at harvest. The data obtained is calculated by the formula for the percentage of mortality Effendi, 1979, as follows:

Description:

$$
M=\frac{A}{B} \times 100 \%
$$

$\mathrm{M} \quad$ = Percentage of mortality

A = Number of dead shrimps for maintenance

$\mathrm{B}=$ Amount stocked at the start of maintenance

Life sustainability

Survival is the level of life of shrimp in a certain period compared to the initial population. Survival Rate (SR) according to Effendi, (2004) can be calculated by the formula:

Description:

$$
S R=\frac{\mathrm{Nt}}{\mathrm{No}} \times 100 \%
$$

$\mathrm{SR} \quad=$ Survival (\%)

$\mathrm{Nt} \quad=$ Number of live shrimps at the end

No = Number of shrimps stocked at the beginning of maintenance

Water Quality Check

During shrimp rearing, water quality measurements from the rearing container were measured on the 1 st day of rearing and the 2 nd day of the end of rearing. Measurements were taken in the morning, afternoon, and evening. The water quality parameters observed included temperature, salinity, $\mathrm{DO}$ and $\mathrm{pH}$.

Data analysis

The data obtained from this study were analyzed using descriptive analysis methods and non-variant analysis (ANOVA). Descriptive analysis was carried out in interpreting data on clinical symptoms that occurred in shrimp. Analysis of Variance (ANOVA) was performed in interpreting shrimp survival and mortality data.

\section{RESULT}

\section{Clinical Symptoms}

The clinical symptoms of vaname shrimp seen after being infected with Vibrio alginolyticus can be seen in table 1 . 
Journal of Fish Health Vol. 1 (2) - Dec 2021

Alifia et al. (2021)

https://doi.org/10.29303/jfh.v1i2.230

Table 1. Clinical Symptoms of Vaname Shrimp Infected with Vibrio alginolyticus

\begin{tabular}{|c|c|c|c|c|c|c|}
\hline \multirow[t]{2}{*}{ Treatment } & \multicolumn{6}{|c|}{ Clinical Symptoms (Hours) } \\
\hline & 3 & 6 & 9 & 12 & 24 & 48 \\
\hline A1 (control) & - & - & - & - & - & - \\
\hline A2 (control) & - & - & - & - & - & - \\
\hline $\begin{array}{c}\text { A3 (control } \\
\text { ) }\end{array}$ & - & - & - & - & - & - \\
\hline $\mathrm{B} 1\left(10^{3}\right)$ & $a, b$ & $a, b$ & c & C & c & c \\
\hline B2 $\left(10^{3}\right)$ & $a, b$ & $a, b$ & c & C & c & c \\
\hline B3 $\left(10^{3}\right)$ & a.b & $a, c$ & c & C & c & c \\
\hline C1 $\left(10^{5}\right)$ & $a, b$ & $b, c$ & $d, e$ & $d, f$ & $d, f$ & $d, f$ \\
\hline $\mathrm{C} 2\left(10^{5}\right)$ & $a, b$ & $b, c$ & $c, e$ & $c, f$ & $c, f$ & $c, f$ \\
\hline C3 $\left(10^{5}\right)$ & $a, b$ & $a, b$ & $c, e$ & $d, f$ & $d, f$ & $d, f$ \\
\hline D1 $\left(10^{7}\right)$ & $a, b$ & $b, g$ & $c, f, g$ & $c, f, g$ & $c, f, g$ & $c, f, g$ \\
\hline D2 $\left(10^{7}\right)$ & $a, b$ & $b, g$ & $c, f, g$ & $c, f, g$ & $c, f, g$ & $c, f, g$ \\
\hline D3 $\left(10^{7}\right)$ & $a, b$ & $b, g$ & $c, f, g$ & $c, f, g$ & $c, f, g$ & $c, f, g$ \\
\hline
\end{tabular}

A Treatment

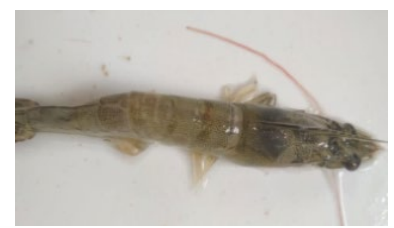

Figure 1. Normal vaname shrimp

B Treatment

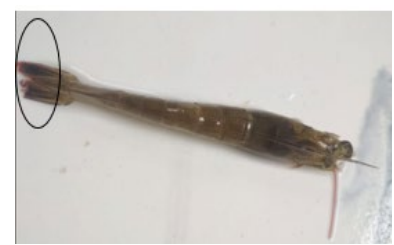

Figure 2. Shrimp tail blushing

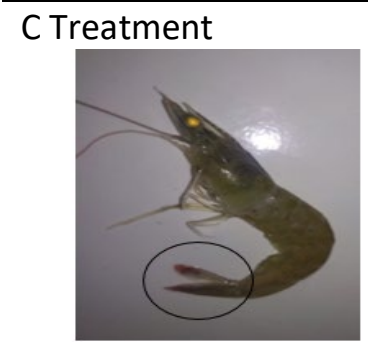

a.

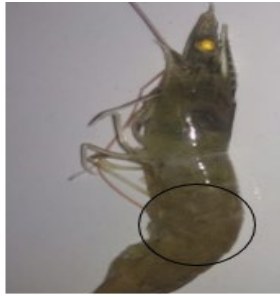

b.

Figure 3. a. Shrimp tail flushed, b. Necrosis

D Treatment

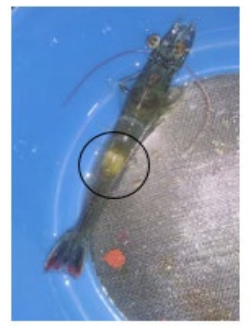

a

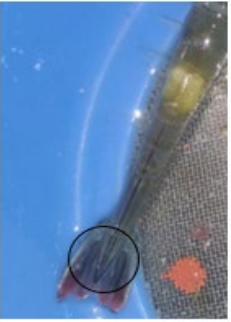

b

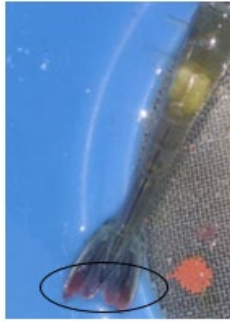

C

Figure 4.a. Body segment necrosis, b. Intestinal necrosis, c. red tail 
Journal of Fish Health Vol. 1 (2) - Dec 2021

Alifia et al. (2021)

https://doi.org/10.29303/jfh.v1i2.230

Mortality

The results of observations on mortality can be seen in table 2 .

Table 2. Mortality of Vaname Shrimp

\begin{tabular}{|c|c|c|c|}
\hline \multirow[t]{2}{*}{ Treatment } & \multicolumn{2}{|c|}{ Day (\%) } & \multirow{2}{*}{ Total \% } \\
\hline & D1 & D2 & \\
\hline A (Control) & 0 & 0 & 0 \\
\hline $\mathrm{B}\left(10^{3} \mathrm{CFU} / \mathrm{mL}\right)$ & 10 & 0 & 10 \\
\hline $\mathrm{C}\left(10^{5} \mathrm{CFU} / \mathrm{mL}\right)$ & 13,3 & 23,33 & 36,33 \\
\hline $\mathrm{D}\left(10^{7} \mathrm{CFU} / \mathrm{mL}\right)$ & 30 & 30 & 60 \\
\hline
\end{tabular}

Survival Rate (SR)

Survival can be seen in graph 1 and table 3.

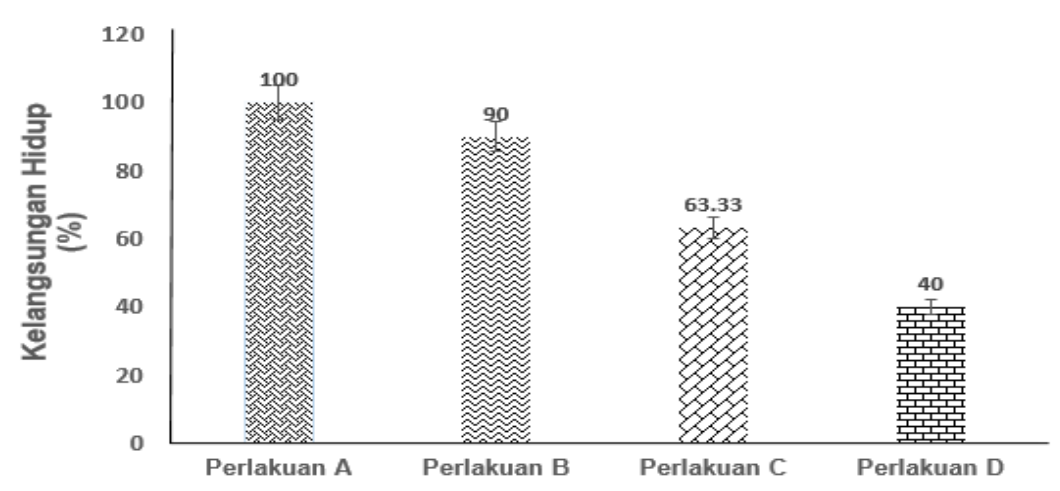

Table 3. Survival Rate (SR)

\begin{tabular}{cc}
\hline Treatment & Average \pm Std. Deviation \\
\hline A (Control) & $100,00 \pm 0,00^{\mathrm{a}}$ \\
B $\left(10^{3} \mathrm{CFU} / \mathrm{mL}\right)$ & $90,00 \pm 0,00^{\mathrm{a}}$ \\
C $\left(10^{5} \mathrm{CFU} / \mathrm{mL}\right)$ & $63,33 \pm 5,78^{\mathrm{b}}$ \\
D $\left(10^{7} \mathrm{CFU} / \mathrm{mL}\right)$ & $40,00 \pm 10,00^{\mathrm{c}}$
\end{tabular}

Notes: Different superscript letters indicate differences between treatments with a $95 \%$ confidence level.

Water quality

Measurement of water quality can be seen in table 4 .

Table 4. Water Quality Data for Vaname Shrimp

\begin{tabular}{|c|c|c|c|c|c|}
\hline \multirow[t]{2}{*}{ Parameter } & \multicolumn{4}{|c|}{ Research Value Range } & \multirow{2}{*}{$\begin{array}{l}\text { Optimal } \\
\text { range } \\
\text { (Amri, } \\
\text { 2003) }\end{array}$} \\
\hline & A Treatment & B Treatment & C Treatment & D Treatment & \\
\hline $\mathrm{DO}(\mathrm{mg} / \mathrm{l})$ & $4-5$ & $4-6$ & $4-6$ & $4-6$ & 3-10 \\
\hline $\begin{array}{l}\text { Temperature } \\
\left({ }^{\circ} \mathrm{C}\right)\end{array}$ & $26-28$ & $26-28$ & $26-28$ & $26-27$ & $26-32$ \\
\hline Salinity (ppt) & $31-33$ & $31-33$ & $31-33$ & $31-33$ & $30-33$ \\
\hline $\mathrm{pH}$ & $7,5-7,6$ & $7,5-7,6$ & $7,4-7,6$ & $7,5-7,6$ & $7,4-8,7$ \\
\hline
\end{tabular}




\section{DISCUSSION}

Observation of clinical symptoms of white shrimp (Litopenaeus vannamei) was carried out after immersion in miana leaf extract ( Coleus scutellarioides (L) Benth) and after infection with Vibrio alginolyticus bacteria. In the first 3 hours, it was shown that there was a change in appetite and loss of balance in treatment $B, C$ and $D$ are thought to be due to vaname shrimp experiencing stress due to the presence of foreign material, namely $V$. alginolyticus. According to Lightner (1988) in Parenrengi et al (2013) stated that one of the bacteria that causes vibriosis is $V$. alginolyticus. Vibriosis causes irregular movement of shrimp, swimming sideways and twisting and causing loss of appetite in shrimp.In this study there were morphological changes in vaname shrimp such as red body organs, necrosis of the tail and melanosis in body segments at 6 hours in treatment $C$ and D. Clinical symptoms that shrimp infected with the bacterium $V$. alginolyticus, namely the red-colored shrimp tail $\mathrm{h}$ brown (Jayasre, 2006), the shrimp body looks pale or soft carapace (Jayasre, 2006) and black spots or melanosis appear. The same thing was also reported by Nasi et al., (2012) that shrimp affected by vibriosis showed symptoms that looked like a blackish back, red spots on the base of the fins, upright scales, sluggish laughter, disturbed balance, and decreased appetite. LavillaPitogo et al (2000) explained that brown tissue lumps that cause the hepatopancreas to look brown are the hepatopancreas tubules that have melanosis. The reddish to black color occurs due to bacterial infection which breaks down the chitin from the exoskeleton causing erosion and reddish pigmentation, dark brown to black. Clinical symptoms caused by vibriosis depend on the level of attack, namely chronic or acute.

At the 9th hour of treatment $B$ (bakery concentration $10{ }^{3} \mathrm{CFU} / \mathrm{mL}$ ) the white vaname shrimp began to show stable movements and at the 24th hour the white vaname shrimp started to eat its food. This is presumably because miana leaf extract contains secondary metabolite compounds. Secondary metabolite compounds can act as an antibacterial and as an immunostimulant. The secondary metabolite compounds possessed by miana leaves are steroids, flavonoids, alkaloids, saponins and tannins (Ridwan et al., 2006). Treatments $C$ and $D$ of white vaname shrimp were still unstable, this was presumably because the number of bacteria was much higher than treatment $\mathrm{B}$, namely $10^{\text {s }}$ and $10^{7}$. According to Feliatra et al (2014) the higher the concentration of infected bacteria, the directly proportional to the pathogenicity of Vibrio sp.

The results of visual observations of vaname shrimp infected with $V$. alginolycus bacteria for 48 hours in treatment $10^{7}$, experienced symptoms of stress such as low appetite seen from being less responsive to feed, swimming without direction, and changing body color from transparent to pale white. The level of pathogenicity some isolates of $V$. alginolitycus on shrimp vaname is $10{ }^{\circ} \mathrm{CFU} / \mathrm{mL}$ at the 12 th hour and 24 th.

The lowest mortality of vaname shrimp infected with $V$. alginolyticus was found in treatment $B$ with a bacterial density of $10{ }^{3} \mathrm{CFU} / \mathrm{mL}$, which was $10 \%$, while the highest mortality was in treatment $D$ with a bacterial density of $10>\mathrm{CFU} / \mathrm{mL}$ of $60 \%$. Based on the results of the tests that have been carried out, it shows that the higher the concentration of $V$. alginolyticus bacteria suspended in the experimental media, the faster the incubation period of the bacteria, causing clinical symptoms in test animals and higher mortality (Table 2). According to Feliatra et al (2014) that the higher the concentration of bacteria suspended in the experimental media, the higher the mortality rate of the test animals. In the study of Feliatra et al (2014) the mortality of shrimp infected with $V$. alginoliticus with concentrations of 10 sand 10 'at 96 hours was $53.3 \%$ and $73.3 \%$, respectively. This shows that the mortality 
Journal of Fish Health Vol. 1 (2) - Dec 2021

Alifia et al. (2021)

https://doi.org/10.29303/jfh.v1i2.230

rate in this study was higher when compared to the use of miana leaves on vaname shrimp infected with Vibrio alginolyticus as was done in this study, namely $36.33 \%$ and $60 \%$, respectively.

The content of compounds possessed by miana leaves by several previous researchers such as increasing immunostimulants and antibacterials such as steroids, flavonoids, as well as alkaloids, essential oils, saponins and tannins (Ridwan and Yunita, 2007). The mechanism of action of steroids as antibacterial is by damaging the lipid membrane, so that liposomes leak (Madduliri et al., 2013). Steroids are also known to interact with phospholipid membranes, due to their permeable nature to lipophilic compounds which causes decreased membrane integrity and disrupted cell membrane morphology so that cells undergo lysis and become brittle.

Flavonoid compounds are antibacterial through 3 mechanisms, namely: inhibiting protein synthesis, inhibiting cell membrane function and inhibiting energy metabolism. Flavonoids kill bacteria by causing damage to the permeability of bacterial cell walls, microsomes and lysosomes as an interaction between flavonoids and bacterial DNA. The mechanism of flavonoids as antibacterial is to form complex compounds with extracellular and soluble proteins which results in phospholipids not being able to maintain the shape of the cell membrane and will leak and bacteria will experience growth inhibition and even death (Sundu et al., 2018). In addition, inhibition of bacterial energy metabolism by flavonoids is carried out by inhibiting the process of bacterial respiration so that the inhibited energy will affect the activity of metabolite absorption and biosynthesis of bacterial macromolecules. In addition, the content of flavonoids, namely quercetin compounds, is able to increase the work of the immune system, where leukocytes as antigen-eaters are produced faster and the lymphoid system is activated more quickly and increases antibody activity. The content of tannin compounds in an extract has antibacterial activity related to its ability to deactivate bacterial adhesins, inhibit enzyme activity, inhibit protein transport in the cell sheath (Cowan, 1999). Terpenoids have an antibacterial mechanism by destroying cell membranes (Cowan, 1999). Damage to cell membranes can occur because antibacterial active compounds react with the active site of the membrane or by dissolving lipid constituents and increasing their permeability. The bacterial cell membrane is composed of phospholipids and protein molecules. The increase in permeability means that antibacterial compounds can enter the cell or coagulate the cytoplasm of the bacterial cell (Maryani et al., 2008).

Saponins are one of the compounds that have antibacterial properties by working effectively on gram-positive bacteria. The mechanism of action of antibacterial saponins is by increasing the permeability of the cell membrane so that the membrane becomes unstable and causes cell hemolysis. Saponins cause leakage of proteins and enzymes from inside bacterial cells so that bacteria will lyse and break (Madduluri et al., 2013; Poeloengan and Pratiwi, 2012). According to Robinson (1995) saponins reduce cell surface tension, resulting in increased permeability or cell leakage and resulting in the release of nuclear cellular compounds. The antibacterial activity of essential oils associated with three mechanisms among other causes cell membranes are in a hypertonic environment that inhibits the formation of the cell wall, lysing the cell membrane by dissolving the phospholipids, and berinteraksinya hydroxyl group with carbonyl groups and bacterial cell membrane proteins so that these proteins lose their function. Proteins and phospholipids are important compounds in compiling bacterial cell membranes that function as regulators of entry and exit of materials into and out of cells. The components suspected of having an active role as antibacterial are sabinene, ${ }^{2}$-mirsen, trans-karyophyllene, and phenol. Immunostimulants are thought to be 
Journal of Fish Health Vol. 1 (2) - Dec 2021

Alifia et al. (2021)

https://doi.org/10.29303/jfh.v1i2.230

related to the content of essential oils, because essential oils have the ability to increase endurance.

The highest survival rate of vannamei shrimp was found in treatment $A$ (control) and treatment $B\left(10{ }^{3} \mathrm{CFU} / \mathrm{mL}\right)$ which was $100 \%$ and $90 \%$, while the lowest survival rate of vannamei shrimp was found in treatment $D(10, \mathrm{CFU} / \mathrm{mL})$ of $40 \%$. The survival rate of vaname shrimp in treatment $\mathrm{B}\left(10{ }^{\mathrm{C}} \mathrm{CF} / \mathrm{mL}\right)$ was $90 \%$, presumably because white vaname shrimp still had good body resistance to $V$. alginolyticus. This is thought to be due to the presence of compounds contained in immunostimulants. Administration of immunostimulants can increase the body's defense of shrimp and can increase the survival of shrimp up to $86 \%$. The survival rate of vaname shrimp in treatment $\mathrm{D}(10>\mathrm{CFU} / \mathrm{mL})$ was the lowest at $40 \%$, presumably because the bacteria used were higher than other treatments. According to Feliatra et al (2014) the higher the concentration of bacteria, the lower the survival rate of vaname shrimp. However, when compared with previous studies conducted by Feliatra et al (2014) without using additional immunostimulant tiger shrimp exposed to $V$. alginolyticus with a bacterial concentration of 10 'had a lower survival rate of $26.3 \%$. This shows that the miana leaf extract is able to increase the immunostimulant in the vannamei shrimp body. Giving immunostimulants to shrimp has no side effects and is very good to be applied to organisms that do not have memory cells in their immune system so that they can stimulate or maximize non-specific immune responses. Giving a good immunostimulant must pay attention to the optimal dose, where the dose of the immunostimulant application is one of the factors that affect the increase in the immune response in shrimp. This is in accordance with the opinion of Couso et al (2003), which states that high doses of immunostimulants can suppress defense mechanisms, while low doses are not sufficient or less effective to provide an immune response.

Water quality parameters measured during the study included temperature (temperature), dissolved oxygen (DO), $\mathrm{pH}$, and salinity. Measurements were taken in the morning, afternoon, and evening. Overall, the value of water quality obtained is still in the range that is feasible for maintenance.

\section{CONCLUSION}

Based on the results of this study, it can be concluded that clinical symptoms in the handling of white shrimp using miana leaf extract against Vibrio alginolyticus bacteria in treatment $A$ (control) shrimp under normal conditions, treatment $B(103 \mathrm{CFU} / \mathrm{mL})$ red shrimp tails, treatment $\mathrm{C}(105 \mathrm{CFU} / \mathrm{mL})$ red shrimp tail and necrosis on the body and treatment $\mathrm{D}(107 \mathrm{CFU} / \mathrm{mL})$ shrimp tail reddened, necrosis on the tail and body segments. The use of miana leaf extract had a significant effect $(p<0.05)$ on the viability of vaname shrimp. The highest vaname shrimp survival was treatment $A$ (control) at $100 \%$, treatment $B(103 \mathrm{CFU} / \mathrm{mL})$ at $90 \%$, treatment $\mathrm{C}$ at $63.33 \%$ and treatment $\mathrm{D}(107 \mathrm{CFU} / \mathrm{mL})$ at $40 \%$.

\section{ACKNOWLEDGMENT}

The authors thank the Balik Diwa Institute of Technology and Maritime Business for accommodating and facilitating this research. 


\section{REFERENCES}

Amri K. (2003). Intensive Windu Shrimp Cultivation. Jakarta: Agro Media Library.

Briggs $M$, Smith, SF, Subasinghe R and Phillips M. 2004. Introduction and Movement of Penaeus vannamei and Penaeus stylirostris in Asia and The Pacific. RAP Publication 2004/10: 136-140.

Cowan M. (1999). Plant Products as Antimicrobial Agents, Clin Microbiol Rev, 12 (4). 564-582. Effendi I. (2004). Introduction to Aquaculture. Self-Help Spreader. Jakarta.

Effendi M I. (1979). Fisheries Biology Methods. Bogor: Dwi Sri Foundation Publisher.

Felitra. (1999). Identification of Pathogenic Bacteria (Vibrio sp) in Nongsa Batam Waters, Riau Province. Indonesian Journal of Nature, 11 (1). 22-33.

Jayasree, Janakiram L, P and Madhavi R. (2006). Characterization of Vibrio spp. Associated with Diseased Shrimp from Culture Ponds of Andhra Pradesh (India). Journal of the World Aquaculture Society, 37 (4). 523 pp.

Lavilla-Pitogo, C. R; GD Lio-Po; ER Cruz-Lacierda; EV Alapide-Tendencia; LD De La Pena. (2000). Disease of Peneid Shrimps in the Philippines. 2nded., Southeast Asian Fiheries Development Center, Philippines., $96 \mathrm{p}$

Lightner DV and Bell T A. (1998). A Handbook of Normal Penaeid Shrimp Histology. Baton Rouge, La World Aquaculture Society, 7 (1). 1114.

Madduliri Suresh, Rao KB and Sitaram B. (2013). In Vitro Evaluation of Five Indegenous Plants Extract Against Five Bacterial Pathogens of Human. International Journal of Pharmacy and Phrmaceutical Science, 5 (4). 679-684

Maryani DD and Sukenda. (2002). Role of Leaf and Fruit Extract of Mangrove Sonneratia caseolaris (L) against Vibrio harveyi bacterial infection in tiger prawns (Penaeus monodon FAB). Indonesian Journal of Aquaculture, 1 (3). 129-138.

Nasi L, Prayitno SB and Sarjito. (2001). Study of Bacteria that Cause Vibriosis in Shrimp Biomolecularly. Diponegoro University.

Parenrengi A, Tenriulo A and Tampangallo B R. (2013). Transgenic Windu Shrimp Penaeus Monodon Challenge Test Using Pathogenic Bacteria Vibrio harveyi. Indonesian Aquaculture Conference. Maros Brackish Water Cultivation Research and Development Center, South Sulawesi.

Poeloengan M and Pratiwi P. (2012). Antibacterial Activity Test of Mangosteen Peel Extract (Garcinia mangostana Linn). Health Research and Development Media, 20 (2). 65-69.

Rahayu M (1999). Plants Resources of South-East Asia. 1st ed. Vol. 12. Prosea Foundation by Backhuys Publishers. Wegeningen. 408- 409 pp.

Ridwan Y and Ayunita Y Q. (2007). Phytochemical and Anthelmint Activity Against Chicken Tuperworm of Painted Nettle (Coleus Blumei (Benth) Varietes In Vitro, 14 (1). 17-21.

Ridwan Y, Satrija, Darusman LK and Handrayani F. (2010). Effectiveness of Miana Leaf Extract Anticestodes (Coleus blumei Bent) against Hymenolayer microstoma Worms in Mice. Journal of Animal Science and Technology, 33 (1). 6-11.

Robinsom T. (1995). High Plant Organic Content. Publisher: ITB. Bandung. 